УАK 342.55

ББК 67.400 .7

DOI 10.22394/1682-2358-2021-5-31-38

L.Yu. Mkbitaryan, Candidate of Sciences (Law), Docent of the Theory and History of State and Law Department, Perm State University

\section{SPECIFIC FEATURES OF PUBLIC HEARING IN THE POST-COVID SPACE AS A FORM OF INTERACTION OF CIVIL SOCIETY WITH THE STATE}

Regulatory legal acts of the federal, regional and municipal levels, which regulate the concept and the procedure for holding public hearings are analyzed. Proposals to make the results of public hearings imperative, as well as the need to involve specialists in matters requiring special knowledge at the stages of preparation and holding of public hearings are formulated.

Key words and word-combinations: local government, public hearings, public discussions, forms of public control, civil society.
М.Ю. Мхитарян, кандидат юридических наук, дочент кафедры теории и истории государства и права Пермского государственного начионального исследовательского университета (email:LMbitaryan@yandex.ru)

\section{ОСОБЕННОСТИ ПРОВЕАЕНИЯ ПУБАИЧНЫХ САУШАНИЙ НА ПОСТКОВИАНОМ ПРОСТРАНСТВЕ КАК ФОРМА ВЗАИМОАЕЙСТВИЯ ГРАЖААНСКОГО ОБЩЕСТВА И ГОСУААРСТВА}

\footnotetext{
Аннотация. Анализируются нормативные правовые акты федерального, регионального и муниципального уровней, регулирующие понятие и порядок проведения публичных слушаний. Сформулированы предложения о придании результатам публичных слушаний императивного характера, а также о необходимости привлечения специалистов к решению вопросов, требующих специальных знаний, на этапах подготовки и проведения публичных слушаний.

Ключевые слова и словосочетания: местное самоуправление, публичные слушания, общественные обсуждения, формы общественного контроля, гражданское общество.
}

$\mathrm{Y}$ Vem ния - мировая практика. Использование общественных слушаний начацось 
после процесса огоражкивания государственных земель, который произошел в Великобритании в XVIII-XIX вв. Публичные собрания проводились Аля создания петиџии в парламент об ограждении земли, а также с целью выслушать возражкения против закона, принятого парламентом [1].

В настоящее время публичные слушания в зарубежкных странах ста$\Lambda и$ Аостаточно привычным явлением - например, в США их провоАят более $97 \%$ местных органов власти. Политологи Э. Уильямсон и А. Фунг заявмяют, что «общественные слушания, возможно, явцяются наиболее распространенным местом общественного участия в Соединенных Штатах, используемым властями всех уровней дмя размичных целей» [2].Исследователь К. Карповиц утверждает, что общественные слушания явцяются критически важными институтами Аля выражения общественного мнения [3] . ОАнако отметим, что в Соединенных Штатах Америки результаты публичных слушаний не имеют обязательного значения дмя органа муниципалитета, проводящего эту процедуру, скорее слушания просто дают гражданам возможность поделиться своим мнением. В Аании, напротив, результаты независимой экспертизы и преАложения граждан, полученные в результате проведения публичных слушаний, обязательны Аля исполнения [4, с. 64].

В Российской Федерации публичные слушания в соответствии со ст. 18 Федерального закона от 21 июля 2014 г. № 212-Ф3 «Об основах общественного контроля в Российской Федерации» (Аалее Закон № 212-Ф3) [5] явмяются оАной из форм общественного контроля наряау с общественным мониторингом, общественным обсужАением и Аругими формами взаимодействия институтов гражАанского общества с государственными органами и органами местного самоуправления [6, с. 38].

Понятие «пубцичные слушания» закреплено в российском законодательстве, хотя практика их проведения мишь нарабатывается. Под общественными (публичными) слушаниями понимается собрание граждан, организуемое органами государственной вцасти, местного самоуправмения, мибо иными органами и организациями, осушествляющими в соответствии с законодательством отдельные пубцичные полномочия, Аця обсуждения вопросов, имеющих особую общественную значимость мибо затрагивающих права и свободы человека и гражданина, права и законные интересы общественных объединений и иных негосударственных некоммерческих организаций [5, ст. 25].

При этом в законодательстве отождествцены понятия «пубцичные слушания» и «общественные обсуждения», что следует из текста 
ст. 28 Федерального закона от 6 октября 2003 г. № 131-Ф3 «Об общих принщипах организащии местного самоуправления в Российской Федерации» (дамее - Закон № 131-Ф3) [7], что явмяется достаточно спорным [8, с. 887], поскольку Закон № 212-Ф3 закрепляет эти понятия как отдельные формы взаимодействия институтов гражданского общества и органов пубцичной власти.

Публичные слушания проводятся в случаях, установленных как федерацьными законами, так и законами субъектов РФ, а также муниципацьными нормативными правовыми актами. Помимо указанных Аокументов, вопросы, связанные с публичными (общественными) слушаниями, на федеральном уровне регулируются также Градостроительным кодексом РФ, Федеральным законом от 8 декабря 2003 г. № 165-Ф3 «О специальных защитных, антидемпинговых и компенсационных мерах при импорте товаров» и рядом Аругих актов.

В последнее время в указанных нормативных актах произошии немаловажные изменения. Так, с 1 июля 2021 г. вступил в силу Федеральный закон № 191-Ф3 [9], расширяющий возможности участников общественных обсуждений и пубцичных слушаний (изменение внесено в п. 3 ч. 10 ст. 5.1 Градостроительного кодекса РФ). В период размещения проекта, подмежкащего рассмотрению на общественных обсуждениях или пубцичных слушаниях, и информационных материамов к нему и проведения экспозиџии такого проекта участники обсуждений (слушаний), прошедшие идентификацию, имеют право вносить преАложения и замечания в адрес организатора в форме электронного Аокумента.

Порядок проведения слушаний регламентируется как на федеральном (Закон об общественных слушаниях, Градостроительный кодекс РФ, Закон № 131-Ф3), так и на региональном, а также муниципальном уровнях.

Проведение публичных слушаний в онлайн-режкиме федеральным законодательством прямо не предусмотрено. Такой вывод подтверждается п. 4 ст. 25 Закона № 212-Ф3, закрепляющим, что обшественные (пубцичные) слушания проводятся пубцично и открыто.

ОАнако начиная с 2020 г. в деятельность органов государственной власти и местного самоуправления были внесены коррективы, связанные с введением ограничительных мер в условиях пандемии коронавирусной инфекции (COVID-19). В связи с этим следует признать своевременным принятие Федерального закона от 1 июля 2021 г. № 289-Ф3 [10], вносящего изменения в ст. 28 Федерального закона «Об общих прин- 
ципах организации местного самоуправления в Российской Федерации», в соответствии с которым публичные слушания отныне можнн будет проводить через Интернет, в том числе посреАством использования сайта «Госускуги».

На региональном уровне вопросы, связанные с понятием и порядком проведения публичных (общественных) слушаний, регулируются уставами и законами субъектов РФ. Так, в Пермском крае слушания проводятся в соответствии с Уставом Пермского края [11, п. 2 ст. 11], Законом Пермского края от 21 декабря 2011 г. № 888-ПК (Аалее - Закон № 888-ПК) «Об общественном контроме в Пермском крае» [12], а также иными нормативными правовыми актами. Например, в Законе Пермского края № 111-ПК «О бюджетном процессе в Пермском крае» в качестве Приложения № 2 закрепляется Регламент организации и проведения публичных слушаний, общественных обсуждений по проекту закона о бюджете Пермского края и по годовому отчету об исполнении бюджета Пермского края.

В муниципальных образованиях регулирование рассматриваемых общественных отношений осуществляется с помощью двух видов правовых актов: устава муниципального образования и нормативных актов преАставительных органов местного самоуправления. Так, Положение о пубцичных слушаниях в городе Перми, принятое Пермской городской Аумой [13], определяет круг вопросов, иниџиаторов провеАения и т.п. Вопросы, выносимые на слушания, и соответствующие нормативные акты, регулирующие порядок проведения слушаний, преАставмены в табцице.

Таким образом, порядок проведения пубцичных слушаний только в одном муниципальном образовании регулируется четырьмя разными нормативными актами, что, на наш взгляд, не способствует эффективности применения этих правиц на практике.

В некоторых регионах в условиях введения режимов повышенной готовности, чрезвычайной ситуации, чрезвычайного положения уже практикуется проведение пубцичных слушаний, общественных обсуждений в режкиме оняайн (городские округа Московской области (Коломна, Ивантеевка), Чита, Симферополь и др.). Определенные мероприятия по переводу публичных слушаний в онлайн-режим проводятся в Перми: так, 21 декабря 2020 г. обсуждение проекта решения Пермской городской Аумы «О внесении изменений в Устав города Перми» проходило в Аистанционном формате. ОАнако подобные случаи в Перми единичны и пока не регулируются действующими муниципальными актами. 
Порядок проведения пубцичных слушаний в городе Перми

\begin{tabular}{|c|c|}
\hline Обсуждаемые вопросы & $\begin{array}{c}\text { Нормативный акт, } \\
\text { регулирующий порядок } \\
\text { проведения публичных слушаний }\end{array}$ \\
\hline $\begin{array}{l}\text { 1. Проект Устава города Перми } \\
\text { 2. Проект решения о внесении изменений } \\
\text { и дополнений в Устав города Перми } \\
\text { 3. Проект бюджета города Перми и отчета } \\
\text { о его исполнении; } \\
\text { 4. Проект стратегии социально-экономиче- } \\
\text { ского развития города Перми } \\
\text { 5. Вопросы о преобразовании муниципаль- } \\
\text { ного образования «Город Пермь» }\end{array}$ & $\begin{array}{l}\text { Положение о публичных слушани- } \\
\text { ях в городе Перми (Решение Перм- } \\
\text { ской городской Думы от } 22 \text { февр. } \\
2005 \text { г. № 32) }\end{array}$ \\
\hline $\begin{array}{l}\text { 1. Проект генерального плана города Перми } \\
\text { 2. Проект о внесении изменений в генераль- } \\
\text { ный план города Перми }\end{array}$ & $\begin{array}{l}\text { Положение о порядке органи- } \\
\text { зации и проведения публичных } \\
\text { слушаний по обсуждению проек- } \\
\text { та решения Пермской городской } \\
\text { Думы о внесении изменений в } \\
\text { Генеральный план города Перми } \\
\text { (Решение Пермской городской } \\
\text { Думы от } 18 \text { дек. } 2012 \text { г. № 286) }\end{array}$ \\
\hline
\end{tabular}

1. Проект правил землепользования и застройки города Перми

2. Проект о внесении изменений в правила землепользования и застройки города Перми 3. Проект документации по планировке территории (проекта планировки территории и (или) проекта межевания территории)

4. Проект внесения изменений в документацию по планировке территории

5. Проект решения о предоставлении разрешения на условно разрешенный вид использования земельного участка или объекта капитального строительства

6. Проект решения о предоставлении разрешения на отклонение от предельных параметров разрешенного строительства, реконструкции объектов капитального строительства

1. Проект правил благоустройства территории города Перми

2. Проект, предусматривающий внесение изменений в правила благоустройства территории города Перми
Правила землепользования и застройки города Перми (Решение Пермской городской Думы от 26 июня 2007 г. № 143)
Положение о порядке организации и проведения публичных слушаний по обсуждению проекта правил благоустройства территории города Перми (Решение Пермской городской Думы от 26 марта 2019 г. № 57) 
Указом губернатора Пермского края от 29 июня 2021 г. № 75 «О внесении изменений в указ губернатора Пермского края от 20 августа 2020 г. № 121 “О мероприятиях, реализуемых в связи с угрозой распространения новой коронавирусной инфекции (COVID-19) в Пермском крае"» [14] до участия в публичных мероприятиях допускаются только граждане, вакщинированные против новой коронавирусной инфекщии (COVID-19); мибо граждане, представившие отрицательный результат исследования, проведенного не позднее чем за 72 часа до начала мероприятия методом ПЦР; мибо граждане, перенесшие инфекщию за последние полгода. При этом предельное количество Аиџ, которые могут одновременно находиться на территории проведения мероприятия, не долэно быть более тридцати человек. В связи с принятием указанного документа возникает вопрос: как группа из тридџати человек может высказывать мнения / решать вопросы, касающиеся мимиионного города или всего Пермского края?

Следует признать, что посещаемость пубцичных слушаний в Перми находится на весьма низком уровне. К примеру, на слушаниях, прохоАивших 19 июля 2021 г. по поводу строительства 10-этажного зАания гостиниџы-общежития ОАО «РЖА» (граничащей с природной охраняемой территорией - Черняевским кесом), присутствоваци не более пятнадцати человек. Безусловно, если бы власть провела это мероприятие в онлайн-режкиме, свое мнение по данному вопросу высказало бы несравнимо большее количество житемей Перми.

Низкий уровень активности населения характерен не только Амя Перми - это общая проблема. В США политологи сетуют, что гражАане, посещающие пубцичные собрания, составцяют всего $25 \%$ местного населения [15, с. 315-344] ; в России эти цифры гораздо ниже.

Ответ на вопрос, почему российское население не заинтересовано в участии в столь важных мероприятиях, скорее находится в компетенции политологов и социологов. Тем не менее назовем несколько причин. Во-первых, поскольку большинство публичных слушаний проводится государственными органами по таким вопросам, как планирование или строительство, разговор может быть сугубо техническим, что затрудняет понять суть дискуссии теми, кто не явцяется экспертом в Аанной области. Аля решения этой проблемы следует предварительно не только выкладывать в свободном доступе проекты решений и постановмения о проведении слушаний, но и предоставцять гражАанам возможность услышать мнения специалистов по тому ици иному техническому вопросу дмя принятия взвешенного, обдуманного решения. Во-вторых, власть и население «слушают и не слышат» Аруг Аруга [16]: решение властей в итоге противоречит мнениям, высказанным 
на пубцичных встречах (как это произошло и с ситуацией строительства высотки рядом с Черняевским цесом). ВАасти действуют исключительно формально, проводя слушания в соответствии с нормами, преАусматривающими регламент проведения слушаний, "Аля галочки», а при принятии решения не учитывают рекомендаџии граждан - ведь органы государственной вмасти и местного самоуправления даже не обязаны пояснять населению, по каким причинам те или иные рекомендации не могут быть приняты к исполнению и реализации.

В связи с изложенным можно сделать слеАующие выводы.

Во-первых, в связи с особой ситуацией, вызванной новой коронавирусной инфекцией (COVID-19), необходимо ввести онлайн-режим Аля проведения всех публичных слушаний. Это позволит выступить всем заинтересованным сторонам, а также создать необходимый диамог между органами власти и местным насемением.

Во-вторых, в настоящее время решения пубцичных слушаний имеют скорее рекомендательный, чем обязательный характер, а значит, необязательны к исполнению. Считаем необходимым урегулировать этот вопрос на законодательном уровне, придав решениям публичных слушаний императивную силу Аля исполнения.

В-третьих, следует привлекать экспертов и специалистов Аля консультащий населения, размещать их заключения в открытом доступе наряду с Аругими необходимыми дмя проведения пубцичного слушания материалами, а также организовывать «горячие минии», в ходе которых заинтересованные миџа могли бы задавать вопросы эксперту и получать квалифицированные ответы, поскольку обычно время проведения слушания составляет не более одного-двух часов, в течение которых выяснить все детали преАстоящего голосования крайне сложнно.

В целом следует признать, что публичные слушания как форма реализаџии прав жителей муниципального образования (общественности) на участие в обсуждении проектов муниципальных правовых актов по вопросам местного значения явмяется чрезвычайно важной, поэтому необходимо их совершенствование, в том числе с использованием положительного зарубежного опыта.

\section{Библиографический список}

1. Kemp Ray. Planning Public Hearings, and the Politics of Discourse // Critical Theory and Public Life / ed. J. Forrester. Cambridge: MIT Press, 1988. URL: https://goo.gl/ VPW17N.

2. Williamson A., Fung A. Public Deliberation: Where We Are and Where Can We Go? // National Civic Review 93. No. 4 (Winter 2004): 8. URL: http://www.fisherwilliamson. com/downloads/FungWilliamsonNCR04.pdf. 
3. Karpowitze C. Context Matters: A Theory of Local Public Talk and Deliberative Reform. Paper presented at the annual meeting of the American Political Science Association. Marriott Wardman Park, Omni Shoreham, Washington Hilton, Washington, DC, Sep. 01, 2005: 20. URL: https://research.allacademic.com/one/apsa/apsa05/index. php?click_key=2\#search_top

4. Иванова 3.И., Данилина Н.В. Процедуры проведения публичных слушаний в мировой практике // Интерактивная наука. 2018. № 12 (34). С. 63-65.

5. Об основах общественного контроля в Российской Федерации: Федер. закон от 21 июля 2014 г. № 212-Ф3 (в ред. от 27 дек. 2018 г. URL: http://www.pravo. gov.ru/

6. Куракина С.И. Институт опроса граждан: от рекомендательного результата к императивной форме // Гуманитарные и политико-правовые исследования. 2019. № 2 (5). С. 36-43.

7. Об общих принципах организации местного самоуправления в Российской Федерации: Федер. закон от 6 окт. 2003 г. № 131-Ф3 (в ред. от 1 июля 2021 г.). URL: http://pravo.gov.ru.

8. Ахметова К.С. Институт публичных слушаний: правовая природа, проблемы правового регулирования и реализации в Республике Казахстан // Конституционное и муниципальное право. 2017. № 1. С. 66-70.

9. О внесении изменений в отдельные законодательные акты Российской Федерации: Федер. закон от 11 июня 2021 г. № 191-Ф3 // СЗ РФ. 2021. № 24 (ч. І). Ст. 4209.

10. О внесении изменений в статью 28 Федерального закона «Об общих принципах организации местного самоуправления в Российской Федерации»: Федер. закон от 1 июля 2021 г. № 289-Ф3 // СЗ РФ. 2021. № 27 (ч. І). Ст. 5117.

11. Устав Пермского края от 27 апр. 2007 г. № 32-ПК (в ред. от 7 июня 2021 г. URL: http://pravo.gov.ru.

12. Об общественном контроле в Пермском крае: Закон Пермского края от 21 дек. 2011 г. № 888-ПК (в ред. от 4 апр. 2019 г.). URL: http://www.pravo.gov.ru - 05.04.2019.

13. Об утверждении Положения о публичных слушаниях в городе Перми: решение Пермской городской Думы от 22 февр. 2005 г. № 32 (в ред. от 27 окт. 2020 г.) // Официальный бюллетень органов местного самоуправления муниципального образования город Пермь. 2020. 30 окт.

14. О внесении изменений в указ губернатора Пермского края от 20 авг. 2020 г. № 121 «О мероприятиях, реализуемых в связи с угрозой распространения новой коронавирусной инфекции (COVID-19) в Пермском крае»: Указ Губернатора Пермского края от 29 июня 2021 г. № 75. URL: http://pravo.gov.ru.

15. Carpini Delli, Michael X., Fay Lomax Cook, Jacobs Lawrence R. Participation and Citizen Engagement: A Review of the Empirical Literature // Annual Review of Political Science. 2007. Vol. 7, Issue 1. P. 315-344.

16. Коркунов $К$. Слушают и не слышат: пермяки не понимают, зачем власти проводят публичные слушания. URL: https://social.riafan.ru/region/per$\mathrm{m} / 1395710$-slushayut-i-ne-slyshat-permyaki-ne-ponimayut-zachem-vlasti-provodyat-publichnye-slushaniya. 